\title{
The Independent Directors in the Energy Utilities: An Empirical Analysis
}

\author{
Claudio Becagli \\ Sara De Masi \\ Andrea Paci \\ University of Florence \\ Department of Economics and Management \\ via delle Pandette 32, 50127 - Florence \\ Italy
}

\begin{abstract}
Many commentators and institutional investors believe that independent directors are particularly effective in monitoring CEO and in avoiding managerial opportunistic behaviors. The role of independent directors may be particularly important in the case of public utilities where the government relations and the private-public ownership may divert CEO decisions from the maximization of firm performance. We conduct a study of whether independent directors and other board variables influence the performance, the growth and the dividend policy of European energy utilities. We find evidence that the relationship between firm performance and independent directors is negative and statistically significant. Using different econometric techniques and controlling for the type of control, our results show that independent directors are less concerned with the improvement of the shareholders' value. This suggests that in the public utilities they may be a corporate mechanism that enhances stakeholders' protection and social welfare rather than financial performance.
\end{abstract}

Keywords: Corporate governance; Board-of-directors; Independent directors, Public utility; Firm performance.

\section{Introduction}

Corporate scandals and the financial crisis have led up to the light the issue of corporate governance and, in particular, of the elements that can increase firm and social wealth. Researchers, business people and politicians have focused on this topic analyzing the mechanisms that may decrease the agency costs between managers and shareholders.According to the classical principal-agent framework (Fama, 1980; Fama and Jensen, 1983), shareholders want managers to work in their best interests, that is, to maximize their wealth. In contrast managers can take decisions that can maximize their own utility through the consumption of perquisites or the selection of suboptimal investments. In this context, corporate governance can be particularly effective in monitoring managers and reducing the agency costs.

A number of corporate governance mechanisms have been proposed to ameliorate the principal-agent problem. These mechanisms include a smaller board size, more outsiders on the board, more board meetings, a higher CEO payperformance sensitivity, higher managerial ownership, higher institutional ownership, and stronger shareholder rights. One of these mechanisms that deserves increasing attention is the independent directors. The intuition basis is that independent directors are particularly effective in controlling managers, pushing them to make decisions to increase shareholder wealth. In other words, independent directors could reduce agency costs because they are more likely to monitor managers than executive directors. Moreover, since they are experts in the field, they use their experience to understand which decisions can really improve firm performance. Theoretically, boards dominated by independent directors may have a positive effect on firm results. However, research shows that the independent directors could have no effect or could reduce firm performance (Yermack, 1996; Core et al., 1999; Bhagat and Black, 2001; Fernandes, 2005; Kumar and Sivaramakrishnan, 2008).

One of the possible reasons is that most of the previous studies focus mainly on manufacturing firms. Gertner and Kaplan (1996) argue that optimal governance may differ across industries, making it difficult to identify the effect of governance on performance. In our research we concentrate on the public utilities that provides specific corporate governance features that make them an interest case to study. Firstly, the public utilities have experienced relevant changes in the last years (Osborne and Brown, 2005; Calabrò et al., 2013). Starting from the 90s, significative reforms about privatization and market liberalization have been introduced (Grossi, 2007). As result, most firms today experience a public-private ownership where private investors interact with public owner. This means that the maximization of the profits might be not a primary goal. 
According to Martinez et al. (2013), public utilities are constantly affected by a tradeoff between integrated wider social goals and managerial effectiveness, measured in terms of shareholders value. Secondly, compared to privately owned enterprises, they are subject to wider political control and influence. Directors in the public utilities are likely to be politicians and their incentive to act upon personal interests rather than stakeholders' ones can become a concern. Specifically, the business-government relations may favor rent expropriation by directors-politicians (Barontini \& Bozzi, 2008; Menozzi et al., 2012). In this context, the role of independent directors in public utilities is much more relevant and controversial than in other sectors.

This article evaluates the effect of the independent directors upon firm performance, dividend policy, and firm growth for listed public utility firms of the energy sector. Specifically, we analyze public utilities' governance characteristics in Italy, Spain, France and United Kingdom from 2002 to 2009. This period is particularly interesting because of the changes in terms of corporate governance and ownership that are affected the public utilities. In order to solve the endogeneity problem that affects this study when we consider ownership, we use also the GMM method. This approach provides more accurate estimations, enabling us better to test for the linkages between board structure and firm performance, dividends and firm growth.

We aim to contribute to the intense debate on public utilities corporate governance (Ferlie et al., 2005; Tillmar, 2009; Menozzi et al., 2012; Monteduro, 2014) investigating the mechanisms that allow the design of effective public utilities corporate governance. Specifically, we contribute to the literature by showing that independent directors as a monitoring mechanism, do not directly increase the value for shareholders. This result suggests that independent directors in the public utility may be a mechanism potentially capable of mitigating the trade-off between the pursuit of the public interest and firm performance.

\section{Literature Review and Hypothesis Development}

In the last decades the introduction of new corporate governance codes in Europe has led to an increase of the number of independent directors. This pattern reflects the common view that one of the principal tasks for a board is to monitor management and that independent directors can control it better than others. But in academic literature, the effects of having board independence are still not conclusive.

Some papers examine contemporaneous correlations between accounting measures of performance and the proportion of outside directors on the board. They analyzed the issue considering outsiders as controllers of executive actions (Hermalin and Weisbach, 1991; Mehran, 1995). Actually, to be a "real" controller and simultaneously take part in decisions, they should distinguish between outsider and independent directors. Hermalin and Weisbach (1998) and Bhagat and Black (2001) study relationships between accounting performance measures and the fraction of outside and independent directors on the board in US companies, reporting no significant results. Another approach, suggested by the work of Morck et al. (1988), is to use Tobin's Q as a performance measure, the idea being that it reflects the added value coming from intangible factors such as governance. Using this method Hermalin and Weisbach (1991) find no noticeable relationship between the proportion of independent directors and Tobin's Q. Instead Bhagat and Black (2001) examine the effect of board composition on long-term stock market and accounting performance and find that greater board independence does not improve, and may reduce, firm performance. MacAvoy and Millstein (1999) argue that one reason why researchers have generally failed to detect a relationship between measures of board independence and firm performance is that they have used "old" data, data that preceded boards taking an activist role. In their study, MacAvoy and Millstein (1999) find evidence that their proxy for independence (CalPERS' grading of board procedures) is positively correlated with accounting-based measures of performance.

All the empirical studies discussed above consider US companies. Results can be different if we consider other markets. Krivogorsky (2006), Garcia-Meca and Sanchez-Ballesta (2006), and Palmberg (2015) found respectively that, for continental European firms listed in US, for Spanish firms and for Sweden companies, the relationship between the portion of independent directors on the board and firm performance is positive and statistically significant. In a recent study Moursli (2019) showed that Swedish firms that have a greater board independence experience larger decrease in their market valuation compared with the rest of the firms in his sample. This result is not explained by the status of independent directors per sè. It is the result of the busyness of independent directors. Results can be different if we consider other industries. According to the definition given by European Commission, public utility companies offer services of general interest. Specifically, they should provide "efficient and no-discrimatory service". According to this view they should consider not only the maximization of shareholders' value but also the enhancement of social welfare. For this reason, they may be less concerned of shareholders' value. This argument leads to the first hypothesis.

H1: The relationship between the portion of independent directors and firm financial performance in public utilities in some European countries is negative. 
Independent directors should monitor CEO's actions and they also guarantee firm growth in the long run. Hence, we expect a positive relationship between board independence and firm growth.

H2: The portion of independent directors has a significant positive relationship with the firm growth.

In the literature the relationship between board independence and dividends policy have been studied through the lens of agency theory. Specifically, agency theory predicts that substantial and stable dividends can solve problems between principal and agent. In particular, the higher dividends are, the less free cash flow there is, ceteris paribus, in managers' hands to spend on negative net present value projects (Bhagat and Black, 2001). Prior empirical studies have demonstrated the positive association between independent directors and shareholder protection in US firms (Clark, 2005; Zahra and Pearce, 1989), and more specifically, in the context of the propensity to pay dividends (Farinha, 2003; $\mathrm{Hu}$ and Kumar, 2004). However, independent directors may be more or less effective in addressing agency conflicts between management and shareholders (Sharma, 2011) if we consider different contexts than US manufacturing firms. Gugler (2003) found that in the Austrian market state controlled firms engage in dividend smoothing and they are most reluctant to cut dividends when cuts are warranted. This is because higher dividends are interpreted as a good signal by the market about the good state of the firms. Hence independent directors are positively related to dividends because they have incentives to signal their reputation and managerial competence to the market (Fama and Jensen, 1983; Linck et al., 2008; Weisbach, 1988). An opposite view is that having less dividends means having more financial resources to reinvest in the firm and for the firm growth. As consequence, when growth opportunity is high, shareholders may find it optimal to wait for their dividends (La Porta et al., 2000; Fama and French, 2001). So, related to the previous hypothesis, since independent directors should guarantee the firm growth, it is reliable to hypothesize that they affect negatively dividend policy.

H3: The relationship between the portion of independent directors and dividends is negative in the firm with high growth opportunity.

\section{Methods, Data and Variables}

We report evidence from 43 listed public utility companies of energy sector in Italy, France, Spain and United Kingdom. The panel is formed by 344 year-observations for a period from 2002 to 2009. We use this time period to avoid that the results could be affected by the potential effect of European financial crisis. Data are collected from different sources: financial data come from Datastream- World scope database and data about board structure and board composition are hand collected, downloading the annual corporate governance reports from company's website. We examine the effect of independent directors on three dependent variables: (1) firm performance such as Tobin's Q; (2) dividend per share, and (3) firm growth measured as the difference between the logarithm of total assets at the end of the year and the logarithm of total assets of the previous years. We follow the common practice of dividing directors into inside director (those who are currently officers in the company), outside director (those who are not a current employee but that are likely to have business relationships with the company, such as investment bankers and lawyers; or who was an officer in the recent past or who are relatives of employees) and independent director (outside directors without such affiliations). We include a dummy variable to indicate whether CEO is also Chairman. It is argued that good governance is associated with the separation of these roles. If CEO is also Chairman, this power concentration can be view as a way to impede the supervisory ability of the board (Bebchuck and Fried, 2004).

The regressions are controlled for firm size, countries and sectors (divided in gas, electricity and multi-utility that provide also energy). Since we have a panel of firms, with data both across firms and over time, we use different techniques to obtain consistent estimates. First, we use fixed effect method. This methodology allows us to control for the unobserved (time-invariant) firm effects that influence the dependent variable (firm performance, dividend policy and firm growth) and cannot be measured. The estimation process has been carried on considering the possibility that there exist a correlation between firm fixed effects (unobservable heterogeneity) and independent variables.

The models that we test using FE are:

$Q_{i t}=\beta_{1}$ Ind $_{i t}+\beta_{2}$ Exe $_{i t}+\beta_{3}$ Bsize $_{i t}+\beta_{4} C E O_{i t}+\beta_{5}$ Fsize $_{i t}+\beta_{6} X_{i t}+\varepsilon_{i t}$

Where $Q_{i t}$ is a proxy of firm value computed as the ratio of the market value of equity minus book value of equity plus book value of assets to the book value of assets (Palia, 2000). Ind ${ }_{i t}$ and $E x e_{i t}$ are respectively the ratio of independent over the board size and the ratio of executive directors over the board size; Bsize $e_{i t}$ is the total number of directors on the board and $C E O_{i t}$ is a dummy to indicate whether CEO is also Chairman. Fsize $e_{i t}$ is a measure of firm size that we proxy with market capitalization and $X_{i t}$ is dummies for sectors and years. In the equation (1) we test the first hypothesis about the relationship between independent directors and firm performance. 
The second hypothesis is tested considering the following model:

$$
A G R_{i t}=\beta_{1} \text { Ind }_{i t-1}+\beta_{2} \text { Exe }_{i t-1}+\beta_{3} \text { Bsize }_{i t-1}+\beta_{4} C E O_{i t-1}+\beta_{5} F_{s i z e_{i t-1}}+\beta_{6} Q_{i t-1}+\beta_{7} X_{i t}+\varepsilon_{i t} \text { (2) }
$$

Where $A G R_{i t}$ is the growth rate of the firm, measured as the difference between the logarithm of total asset at time $\mathrm{t}$ and the logarithm of total assets at time t-1.

With the third hypothesis we test the effect of board independence on the dividend policy considering these models:

$$
D S_{i t}=\beta_{1} \text { Ind }_{i t}+\beta_{2} \text { Exe }_{i t}+\beta_{3} \text { Bsize }_{i t}+\beta_{4} C E O_{i t}+\beta_{5} \text { Fsize }_{i t}+\beta_{6} \text { eps }_{i t}+\beta_{7} Q_{i t}+\beta_{8} X_{i t}+\varepsilon_{i t}
$$

Where $D S_{i t}$ is dividend per share and it represents the total dividends per share declared during the fiscal year.

As mentioned above, the estimation method used is fixed effect. This method allows controlling for many firm characteristics that are unobservable or difficult to measure and for omitted variables that often affect this kind of models. But if we add the ownership variables, results are affected by the endogeneity and, as consequence, fixed effect method leads to bias estimations (Bhagat and Black, 2001). In fact, board composition is known to be related to the industry (Agrawal and Knoeber, 2001) and to a firm's ownership structure. So, the type of control cannot be considered as exogenous, because it affects board variables such as board composition, board size, or duality between CEO and Chairman. We distinguish the following types of the control: (1) Local Government; (2) Foreign Government; (3) Hedge Funds; (4) Institutional Investors; (5) Private investors, (6) Private equity; (7) National State.

In order to solve the endogeneity problem, we use the GMM method, that consider lagged variable as a set of instruments that control better the individual effects. More specifically, these models estimate a system of level and first-difference equations, using lags as instrumental variables. The results are shown in the next section. Table 1 gives descriptive statistics for the governance variables and for financial data in the sample. Descriptive statistics country by country and the correlation matrix are presented in the appendix.

Table 1 - Descriptive statistics

\begin{tabular}{llllll}
\hline & Obs & Mean & Std. Dev. & Min & Max \\
\hline BSize & 271 & 10.679 & 3.824 & 3.000 & 23.000 \\
\hline Ind_N & 250 & 5.304 & 3.175 & 0.000 & 16.000 \\
\hline Exe_N & 255 & 2.275 & 1.528 & 0.000 & 9.000 \\
CEO & 265 & 0.294 & 0.457 & 0.000 & 1.000 \\
\hline Ind & 250 & 0.485 & 0.236 & 0.000 & 0.889 \\
\hline Exe & 255 & 0.248 & 0.205 & 0.000 & 1.000 \\
\hline TotAsset & 312 & $2.21 \mathrm{e}+07$ & $3.77 \mathrm{e}+07$ & 152.850 & $2.39 \mathrm{e}+08$ \\
\hline Marketcap & 284 & $1.30 \mathrm{e}+07$ & $2.09 \mathrm{e}+07$ & 4334.000 & $1.48 \mathrm{e}+08$ \\
\hline Q & 281 & 1.359 & 0.665 & 0.338 & 8.144 \\
\hline AGR & 301 & 0.096 & 1.064 & -6.204 & 7.123 \\
\hline DPS & 257 & 46.048 & 29.508 & 0.000 & 100.000 \\
\hline DS & 257 & 0.7569 & 1.563 & 0.000 & 9.869 \\
EPS & 304 & 1.123 & 2.735 & -6.547 & 20.95 \\
\hline LocalGov & 324 & 0.182 & 0.387 & 0.000 & 1.000 \\
ForeignGov & 324 & 0.025 & 0.155 & 0.000 & 1.000 \\
\hline Hedge Fund & 324 & 0.068 & 0.252 & 0.000 & 1.000 \\
\hline Inst. Inv. & 324 & 0.275 & 0.447 & 0.000 & 1.000 \\
\hline Private & 324 & 0.052 & 0.223 & 0.000 & 1.000 \\
\hline PrivateEquity & 324 & 0.040 & 0.196 & 0.000 & 1.000 \\
\hline NationalGov & 324 & 0.222 & 0.416 & 0.000 & 1.000 \\
\hline
\end{tabular}

BSize is the total number of independent director in the board. Ind_N and Exe_N are respectively the number of independent directors and executive directors. Ind is portion of independent directors, measured as the ratio between independent directors and total number of directors in the board. Exe is portion of executive directors, measured as the ratio between executive directors and total number of directors in the board. CEOC is a dummy that is equal to 1 if CEO is also Chairman, 0 otherwise. TotAsset is the amount of total assets in the year. Marketcap is market capitalization at the end of the year. Q is Tobin's Q measured as the ratio of the market value of equity minus the book value of equity plus the book value of assets to the book value of assets. AGR is the difference between the logarithm of total asset at time $t$ and the logarithm of total asset at time-1; DPS is dividend payout, computed as the ratio between dividends per share and earning per share times 100 and DS that is dividend per share. LocalGov is when the control comes from the local government; ForeignGov is when the control comes 
from foreign government; HedgeFund is when the control comes from an hedge fund; Fin.Invest is when the control comes from some financial investors such as banks or insurance; Private is when the owner is a private investor; PrivateEquity is when the control comes from a private equity fund; NationalGov is when the control comes from the national government.

\section{Empirical Results}

This section reports the results of the relationship between board variables and firm performance, firm growth and dividends. The regressions contain indicator variables that control for the year, the countries and the sectors (i.e. gas; electricity and multi-utility).

\section{Table 2 - The relationship between independent directors and firm performance}

Dependent variables is Tobin's Q calculated as the ratio of the market value of equity minus the book value of equity plus the book value of assets to the book value of assets. The first column reports the coefficients of board variables at the end of the year and the second column reports the coefficient of lagged board variables.

\begin{tabular}{lll}
\hline & Tobin's Q & Tobin's Q $\mathbf{Q}_{\text {lagged variables }}$ \\
\hline Ind & -0.22 & $-0.44^{* *}$ \\
\hline Exe & $(-1.03)$ & $(-1.86)$ \\
\hline BSize & -0.27 & -0.12 \\
\hline & $(-0.70)$ & $(-0.90)$ \\
\hline CEO & -0.01 & -0.00 \\
\hline & $(-0.36)$ & $(-0.60)$ \\
\hline Fsize & 0.07 & -0.06 \\
\hline R-sq Adjust & $(0.92)$ & $(-1.13)$ \\
\hline F-statistic & $0.28^{* * *}$ & $0.27^{* * *}$ \\
\hline Prob>F & $(3.13)$ & $(4.50)$ \\
\hline
\end{tabular}

The regressions include dummy for countries, sectors and time. T-statistic reported in brackets. *,** and *** denotes significance at $10 \%, 5 \%$ and $1 \%$ respectively. Year effects and country effect are not reported. Ind is portion of independent directors, measured as the ratio between independent directors and total number of directors in the board. Exe is portion of executive directors, measured as the ratio between executive directors and total number of directors in the board. BSize is the number of directors in the board, CEO is a dummy that is equal to 1 if CEO is also Chairman, 0 otherwise, Fsize is logarithmic transformation of market capitalization in the year.

Table 2 presents the effect of independent directors on firm performance measured as Tobin's Q using fixed effect method. The first column documents the effect of board variables on the firm performance at the end of the year. The board variables are not statistically significant. In the second column we consider lagged board variables, in order to test whether the having independent directors on corporate boards can affect the firm performance in the subsequent year. In this case, independent directors variable is statistically significant but the coefficient is negative. It means that an increase in the portion of independent directors leads to a decrease of the firm performance in the subsequent year. This result is consistent with the previous studies about US companies (Yermack 1996, Bhagat and Black 2001, Agrawal and Knoeber 2001). A first explanation of this result could be related to the problem of asymmetric information. Since independent directors are not executive, they take decisions considering information that they receive from CEO and the other executive directors who are likely to give only partial information or information that can support better CEO's decisions. So, if there are no mechanisms that give to independent directors a commitment to improve firm performance (such as reputation, monetary incentives, threat of dismissing, etc), board independence may be an ineffective tool to have good firm results. A second reason could be related to their monitoring role in the public utilities. Independent directors are seen as a corporate governance mechanism to monitor CEO decisions. They may be particularly effective in push CEO towards decisions aimed at the increasing of firm value. This monitoring commitment may be influenced by the government relationship. In the public utilities, where the relationships with governments are very common, independent directors may be less concerned with firm performance, paying more attention to networking with the government than to monitoring. A third explanation is related to the independent directors as a mechanism to enhance the social welfare. Under this view independent directors may be less concerned with the shareholders' value. They may be more interested in decisions that enhance the social welfare. In the second model we test the relationship between having independent directors on boards and firm growth. 
Since firm growth is measured as difference between logarithm of total asset at time $t$ and logarithm of total asset at time $\mathrm{t}-1$, also board variable should be lagged at time $\mathrm{t}-1$. The results show that the independent directors and firm growth have a not significant relationship. The variable related to the executive directors is positive and statistically significant. This shows that an increase in the portion of executive directors leads to an increase in the firm growth. The control variable Boardsize is negative and statistically significant.

The conclusions are similar if we consider the effect of independent directors on dividend policy (Table 3). We use dividends per share (DS) as measures of dividends policy. Correcting for the amount of earnings per share in the year and for the growth opportunity, the results show that an increase in the portion of executive directors in the board leads to a decrease of dividend per share. The relationship between independent directors and dividends per share is not statistically significant.

Table 3 - Effect of board variables on firm growth and dividend policy

Dependent variables are: AGR calculated as the difference between the logarithm of total asset of time $t$ and the logarithm of total asset of time-1; DS that is dividend per share.

\begin{tabular}{lll}
\hline & AGR & DS \\
\hline Ind $_{\mathrm{t}-1}$ & 0.19 & \\
& $(0.33)$ & \\
\hline Exe $_{\mathrm{t}-1}$ & $2.79^{* * *}$ & \\
& $(-2.69)$ & \\
\hline BSize $_{\mathrm{t}-1}$ & $0.15^{*}$ & \\
& $(-1.87)$ & \\
CEO $_{\mathrm{t}-1}$ & -0.35 & -0.63 \\
& $(-0.86)$ & $(-1.26)$ \\
\hline Ind & & $-0.51^{* *}$ \\
& & $(-2.13)$ \\
\hline Exe & & -0.03 \\
& & $(-1.07)$ \\
\hline BSize & & -0.19 \\
& & $(-1.08)$ \\
\hline CEO & & 0.10 \\
& & $(0.58)$ \\
\hline EPS & 0.27 & $0.24^{* *}$ \\
& $(1.22)$ & $(2.35)$ \\
\hline Fsize & 0.20 & 0.12 \\
& 2.84 & 3.48 \\
\hline R-sq Adjust & 0.01 & 0.00 \\
\hline F-statistic & & \\
\hline Prob>F & & \\
\hline
\end{tabular}

The regressions include dummy for countries, sectors and time. T-statistic reported in brackets. *, $* *$ and $* * *$ denotes significance at $10 \%, 5 \%$ and $1 \%$ respectively. Year effects and country effect are not reported. Ind $\mathrm{t}_{\mathrm{t}-1}$ is the portion of independent directors in the previous year, measured as the ratio between independent directors and total number of directors in the board. Exe $\mathrm{t}_{\mathrm{t}-1}$ is the portion of executive directors in the previous year, measured as the ratio between executive directors and total number of directors in the board. Ind is portion of independent directors, measured as the ratio between independent directors and total number of directors in the board. Exe is portion of executive directors, measured as the ratio between executive directors and total number of directors in the board. BSize is the number of directors in the board, CEO is a dummy that is equal to 1 if CEO is also Chairman, 0 otherwise. Fsize is logarithmic transformation of market capitalization in the year and EPS is earning per share.

In all these regressions we do not consider the type of control. Who controls the firm can affect both board characteristics (such as board size, number of executive and independent directors, CEO duality, etc) and firm results. As mentioned before, if the equations include also the variable related to the type of control, fixed effect method leads to bias estimations. In order to solve this endogeneity problem, one approach that has been used in the previous literature is to use instrumental variables for governance mechanisms (Palia, 2000; Brick et al., 2005). However, it is difficult to identify instrumental variables (IV), because each potential IV is likely to be related to another board variable. In such a case, IV will be too weak and the equations will not be identified. 
Further, the fixed-effects approach captures the effect of unobservable characteristics assuming that they are not time varying. But characteristics such as market power, intangibles, monitoring technologies (Himmelberg et al., 1999) and managerial skill (Bertrand and Schoar, 2003) can clearly vary over time decreasing the appropriateness of the fixedeffects approach. Our methodology does not need to identify instrumental variables for each governance mechanism, nor does it need to assume that the unobservable firm characteristics are fixed over time. To test the same models as before, but that includes also the variable of nature of control, we adopt Generalize Method of Moments (GMM), which use a set of lagged variables as instrumental variables. Table 4 presents the results. Contrary as before, the relationship between independent directors and Tobin's Q is statistically significant.

\section{Table 4 - GMM estimation of effect of board variables on firm performance, growth and dividend policy}

Dependent variables are Tobin's Q calculated as the ratio of the market value of equity minus the book value of equity plus the book value of assets to the book value of assets; DS is dividend per share.

\begin{tabular}{|c|c|c|c|c|}
\hline & Tobin's Q & Tobin's $\mathbf{Q}_{\text {lagged variables }}$ & AGR & DS \\
\hline $\operatorname{Ind}_{t-1}$ & & $\begin{array}{l}-1.12 \\
(-1.53)\end{array}$ & $\begin{array}{l}1.41 \\
(1.36)\end{array}$ & \\
\hline Exe $_{t-1}$ & & $\begin{array}{l}0.41 \\
(1.16)\end{array}$ & $\begin{array}{l}4.24 \\
(2.48)^{* *}\end{array}$ & \\
\hline Bsize $_{t-1}$ & & $\begin{array}{l}0.05 \\
(1.45)\end{array}$ & $\begin{array}{l}-0.04 \\
(-0.58)\end{array}$ & \\
\hline $\mathrm{CEO}_{\mathrm{t}-1}$ & & $\begin{array}{l}0.06 \\
(0.33)\end{array}$ & $\begin{array}{l}-1.06 \\
(-2.05) * *\end{array}$ & \\
\hline Ind & & $\begin{array}{l}-0.65 \\
(2.22)^{* *}\end{array}$ & $\begin{array}{l}-0.26 \\
(-0.56)\end{array}$ & \\
\hline Exe & $\begin{array}{l}-1.31 \\
(-1.29)\end{array}$ & & & $\begin{array}{l}-0.33 \\
(-0.38)\end{array}$ \\
\hline Bsize & $\begin{array}{l}-.012 \\
(-1.53)\end{array}$ & & & $\begin{array}{l}-0.02 \\
(-0.46)\end{array}$ \\
\hline CEO & $\begin{array}{l}-0.16 \\
(-0.67)\end{array}$ & & & $\begin{array}{l}-0.32 \\
(-0.74)\end{array}$ \\
\hline Lmktcap & $\begin{array}{l}0.57 \\
(3.24) * * *\end{array}$ & $\begin{array}{l}0.31 \\
(3.07) * * *\end{array}$ & $\begin{array}{l}0.33 \\
(2.01)^{* *}\end{array}$ & $\begin{array}{l}0.10 \\
(1.82)^{*}\end{array}$ \\
\hline LocalGov & $\begin{array}{l}0.59 \\
(0.92)\end{array}$ & $\begin{array}{l}-0.69 \\
(-0.47)\end{array}$ & $\begin{array}{l}0.10 \\
(0.67)\end{array}$ & $\begin{array}{l}0.07 \\
(0.08)\end{array}$ \\
\hline ForeignGov & $\begin{array}{l}-3.40 \\
(-1.60)\end{array}$ & $\begin{array}{l}-1.17 \\
(-0.82)\end{array}$ & $\begin{array}{l}-1.86 \\
(-0.94)\end{array}$ & $\begin{array}{l}1.29 \\
(0.72)\end{array}$ \\
\hline HedgeFund & $\begin{array}{l}-0.25 \\
(-0.19)\end{array}$ & $\begin{array}{l}-0.29 \\
(-0.37)\end{array}$ & $\begin{array}{l}-1.13 \\
(-0.96)\end{array}$ & $\begin{array}{l}-1.56 \\
(-1.40)\end{array}$ \\
\hline Fin.Investor & $\begin{array}{l}-3.40 \\
(-0.65)\end{array}$ & $\begin{array}{l}0.00 \\
(0.00)\end{array}$ & $\begin{array}{l}-0.35 \\
(-0.44)\end{array}$ & $\begin{array}{l}-1.49 \\
(-1.48)\end{array}$ \\
\hline Private & $\begin{array}{l}0.62 \\
(0.55)\end{array}$ & $\begin{array}{l}0.60 \\
(0.61)\end{array}$ & $\begin{array}{l}-0.21 \\
(-0.21)\end{array}$ & $\begin{array}{l}-1.31 \\
(-1.68)^{*}\end{array}$ \\
\hline PrivateEquity & $\begin{array}{l}0.49 \\
(0.50)\end{array}$ & $\begin{array}{l}0.57 \\
(0.48)\end{array}$ & $\begin{array}{l}0.65 \\
(-0.38)\end{array}$ & $\begin{array}{l}-0.56 \\
(-0.61)\end{array}$ \\
\hline
\end{tabular}

The regressions include dummy for countries, sectors and time. Z-statistic reported in brackets. *, $* *$ and $* * *$ denotes significance at $10 \%, 5 \%$ and $1 \%$ respectively. Year effects and country effect are not reported. Ind $\mathrm{t}_{\mathrm{t}-1}$ is the portion of independent directors in the previous year, measured as the ratio between independent directors and total number of directors in the board. Exe $\mathrm{t}_{\mathrm{t}-1}$ is the portion of executive directors in the previous year, measured as the ratio between executive directors and total number of directors in the board. Ind and Exe are respectively the ratio between independent directors and total number of directors and the ratio between executive directors and total number of directors in the board. Bsize is the total number of directors, CEO is a dummy that is equal to 1 if CEO is also Chairman, 0 otherwise, Lmktcap is logarithmic transformation of market capitalization in the year. LocalGov is when the nature of control is local administration; ForeignGov is when the nature of control is a foreign state; HedgeFund is when the nature of control is an hedge fund; Fin.Invest is when the nature of control is some financial investors such as banks or insurance; 
Private is when the nature of control is private; PrivateEquity is when the nature of control is a private equity fund.

This shows that when we control for the type of owner who controls the company, the independent directors variable matters and the relationship is negative. This result suggests again that adding independent director in the board does not mean an increase in the firm financial performance.

Our FE and GMM coefficient estimates for the effect of board variable and firm growth are very similar. Again, independent directors do not influence growth rate but executive directors affect it positively.

Related to the dividend policy the regressions with GMM show that board variables do not affect the level of dividend per share. Considering the type of control, our results confirm the previous studies about state owned firms: dividend per share is less in the private firm than in state owned firm (Gugler, 2003). There are possible explanations. As mentioned above, giving dividends is a good signal for the markets. Since state owned firms are more under the pressure of public opinion, they may prefer to give more dividends than private firm. Furthermore, the increasing constraints imposed on public spending in European countries, push local and national governments to obtain the maximum possible dividend from their companies in order to allocate these resources to other public investments.

\section{Conclusions}

Corporate governance, and in particular the board composition and the role of independent directors, has been the topic of much attention lately. Although this attention is particularly topical due to well-publicized governance failures and subsequent regulatory changes, corporate governance is an area of longstanding interest. Corporations have an enormous share of economic activity in modern economies, and as consequence, the cost of their agency problems and the effect of their corporate governance characteristics are issues of fundamental importance. This argument is much more relevant if we consider regulated sectors such as that of public utility. Public utilities provide a service of general interest and so they should maximize not only shareholders' value but also consumers' wealth.

Given the fundamental importance of corporate governance and its prominent place in the public eye, it is not surprising that in the last years most of European countries have introduced some corporate governance codes, in order to gives guidelines that should be respected to improve firm results. According to these codes, the presence of independent directors in the board is a tool to reduce agency cost and improve firm results.

This paper establishes the effects of board variables on firm performance, growth and dividend policy, focusing on the role of independent directors in the public energy utilities. Our results show that the relationship between independent directors and firm performance is negative and statistically significant. Using different techniques, we report no evidence that more independent boards achieve higher firm growth or reduce dividends per share. We find, instead, that the portion of executive directors in the board increases the firm growth and reduce dividends per share in the shortterm. One reason could be related to the problem of asymmetric information (Kumar and Sivaramakrishnan, 2008). By definition, independent directors are members of the board who do not have affiliation with the company through past and present business relationships or through relative relations with employees. So, they do not have all information about the company. They take decisions considering information that they receive from CEO and the other executive directors, who obviously give information that can support better CEO's decisions. This lack information can reduce their effectiveness of monitoring.

Another possibility is that some directors who are classified as independent are not truly independent, because they are beholden to the company or its current CEO can exert too much influence on board decisions. For example, some nominally independent directors may be employed by a foundation that receives financial support from the company, or some directors can have personal relationships with the CEO that affect their independence. Unfortunately, the data needed to capture these relationships are not available.

A third explanation is that independent directors in the public utility serve wider interests than are not related exclusively to the shareholders' value need. Public utilities have special features that make them different from manufacturing firms: they are regulated and most of them have a private-public ownership that may influence their corporate decisions. So, independent directors may be less concerned with the shareholders' value. They may be more interested in decisions that enhance the social welfare rather than shareholders' returns. Considering all these remarks, we need more research that explores whether the effect of board variables, suggesting an increase in the number of inside directors, might add value. An extension of our study is to consider other measures of firm performance or to add other governance variables related to characteristics of independent directors, such as politically connections, networks or tenure. 


\section{Appendix}

Table A - Descriptive statistic by country (thousands of euro)

\begin{tabular}{|c|c|c|c|c|}
\hline Italy & & & & \\
\hline Board variables & Mean & Median & Min & Max \\
\hline Board Size & 9.87 & 9.00 & 4.00 & 18.00 \\
\hline Independent & 6.06 & 6.00 & 1.00 & 16.00 \\
\hline Executive & 1.64 & 1.00 & 1.00 & 6.00 \\
\hline Not Executive & 2.18 & 1.00 & 0.00 & 1.00 \\
\hline CEOChair & 0.23 & 0.00 & 0.00 & 1.00 \\
\hline PortionIndipendent & 0.60 & 0.70 & 0.01 & 0.89 \\
\hline PortionExecutive & 0.17 & 0.14 & 0.08 & 0.56 \\
\hline Financial variables (th.Euro) & Mean & Median & Min & Max \\
\hline TotAsset & $19,826,570$ & $4,306,183$ & 144,828 & $154,000,000$ \\
\hline Mktcap & $12,496,678$ & $2,161,580$ & 43,121 & $93,776,560$ \\
\hline Tobin's $Q$ & 1.16 & 1.14 & 0.78 & 1.63 \\
\hline Dividendpershare & 0.26 & 0.09 & 0.00 & 1.30 \\
\hline \multicolumn{5}{|l|}{ Spain } \\
\hline Board variables & Mean & Median & Min & Max \\
\hline Board Size & 14.00 & 15.00 & 9.00 & 21.00 \\
\hline Independent & 6.47 & 6.50 & 0.00 & 12.00 \\
\hline Executive & 1.79 & 1.00 & 1.00 & 9.00 \\
\hline Not Executive & 6.11 & 6.50 & 1.00 & 9.00 \\
\hline CEOChair & 0.52 & 1.00 & 0.00 & 1.00 \\
\hline PortionIndipendent & 0.44 & 0.45 & 0.00 & 0.80 \\
\hline PortionExecutive & 0.13 & 0.10 & 0.06 & 0.64 \\
\hline Financial variables (th.Euro) & Mean & Median & Min & Max \\
\hline TotAsset & $22,382,384$ & $10,672,920$ & 35,661 & $88,095,060$ \\
\hline Mktcap & $12,634,784$ & $8,637,600$ & 42,664 & $50,708,580$ \\
\hline Tobin's $Q$ & 1.137 & 1.36 & 0.91 & 1.87 \\
\hline Dividendpershare & 0.65 & 0.48 & 0.00 & 5.89 \\
\hline \multicolumn{5}{|l|}{ United Kingdom } \\
\hline Board variables & Mean & Median & Min & Max \\
\hline Board Size & 8.83 & 9.50 & 4.00 & 14.00 \\
\hline Independent & 4.32 & 4.00 & 0.00 & 8.00 \\
\hline Executive & 3.45 & 3.00 & 0.00 & 6.00 \\
\hline Not Executive & 1.39 & 1.00 & 0.00 & 6.00 \\
\hline CEOChair & 0.04 & 0.00 & 0.00 & 1.00 \\
\hline PortionIndipendent & 0.45 & 0.50 & 0.00 & 0.72 \\
\hline PortionExecutive & 0.39 & 0.40 & 0.00 & 1.00 \\
\hline Financial variables (th.Euro) & Mean & Median & Min & Max \\
\hline TotAsset & $9,334,861$ & $6.955,368$ & 152,850 & $49,915,580$ \\
\hline Mktcap & $8,248,169$ & $3,769,870$ & 20.495 & $49,569,753$ \\
\hline Tobin's $Q$ & 1.50 & 1.31 & 0.33 & 8.14 \\
\hline Dividendpershare & 0.28 & 0.12 & 0.00 & 2.14 \\
\hline
\end{tabular}




\begin{tabular}{l|r|r|r|r}
\hline France & & & & \\
\hline Board variables & \multicolumn{1}{|c|}{ Mean } & Median & \multicolumn{1}{c}{ Min } & \multicolumn{1}{c}{ Max } \\
\hline Board Size & 12.34 & 13.50 & 3.00 & 23.00 \\
\hline Independent & 4.60 & 4.00 & 0.00 & 11.00 \\
\hline Executive & 1.50 & 1.00 & 0.00 & 6.00 \\
\hline Not Executive & 5.64 & 6.00 & 0.00 & 15.00 \\
\hline CEOChair & 0.65 & 1.00 & 0.00 & 1.00 \\
\hline PortionIndipendent & 0.36 & 0.38 & 0.00 & 0.79 \\
\hline PortionExecutive & 0.22 & 0.07 & 0.00 & 1.00 \\
\hline Financial variables (th.Euro) & Mean & & & Max \\
\hline TotAsset & $43,023,781$ & $25,605,505$ & & 7,028 \\
\hline Mktcap & $21,119,052$ & $8,797,522$ & 4,334 & $148,000,000$ \\
\hline Tobin'sQ & 1.41 & 1.33 & 0.94 & 2.64 \\
\hline Dividendpershare & 2.01 & 1.00 & 0.00 & 9.86 \\
\hline
\end{tabular}

\section{References}

Agrawal, A., \& Knoeber, C. R. (2001). Do Some Outside Directors Play a Political Role? Journal of Law and Economics, 44, pp. 179-198.

Barontini, R., \& Bozzi, S. (2008). Executive compensation and ownership structure: empirical evidence for Italian listed companies. [Online] Available: http://www.efmaefm.org (October 6, 2008).

Bebchuk, L., \& Fried, J. (2004). Pay without performance (Vol. 29). Cambridge, MA: Harvard University Press.

Bertrand, M., \& Schoar, A. (2003). Managing with style: The effect of managers on firm policies. The Quarterly Journal of Economics, 118(4), 1169-1208.

Bhagat, S., \& Black, B. (2001). The non-correlation between board independence and long-term firm performance. The Journal of Corporate Law, 27, 231.

Brick, I. E., Palia, D., \& Wang, C. J. (2005). Simultaneous estimation of CEO compensation, leverage, and board characteristics on firm value. Unpublished working paper.

Calabrò, A., Torchia, M., \& Ranalli, F. (2013). Ownership and control in local public utilities: the Italian case. Journal of Management and Governance, 17, pp. 835-862.

Clark, R.C. (2005). Corporate governance changes in the wake of the Sarbanes-Oxley Act: a mortality tale for policymakers too. Harvard Law and Economics Discussion Paper, n. 525, Harvard University.

Core, J., Holthausen, R., \& Larcker, D. (1999). Corporate governance, CEO compensation, and firm performance. Journal of Financial Economics, 51, pp. 371-390.

Fama, E. (1980). Agency Problems and the Theory of the Firm. Journal of Political Economy, 88, pp. 288-307.

Fama, E., \& French, K. (2001). Disappearing dividends: changing firm characteristics or lower propensity to pay? Journal of Financial Economics, 60, pp. 3-43.

Fama, E., \& Jensen, M. (1983). Separation of Ownership and Control. Journal of Law and Economics, 26, pp. 301-25.

Farinha, J. (2003). Dividend policy, corporate governance and the managerial entrenchment hypothesis: an empirical analysis. Journal Business and Finance Accounting, 30, pp. 1173-1209.

Fernandes, N. (2005). Board Compensation and Firm Performance: The Role of Independent Board Members. ECGI Finance Working Paper, 104/2005

Ferlie, E., Lynn, L. E., \& Pollitt, C. (2005). The Oxford handbook of public management. Oxford: Oxford University Press.

Garcia-Meca, E., \& Sanchez-Ballesta, J. P. (2006). The influence of the board on firm performance: an empirical vision in the Spanish capital market. Corporate Ownership and Control, 3(3), pp. 199-204.

Gertner, R., \& Kaplan, S. (1996). The Value-Maximizing Board. Unpublished paper, University of Chicago.

Grossi, G. (2007). Governance of Public-Private Corporations in Provision of Local Italian Utilities. International Public Management Review, 8(1), 132-153.

Gugler, K. (2003). Corporate governance, dividend payout policy, and the interrelation between dividends, R\&D, and capital investment. Journal of Banking and Finance, 27(7), pp. 1297-1321.

Himmelberg, C. P., Hubbard, R. G., \& Palia, D. (1999). Understanding the determinants of managerial ownership and the link between ownership and performance. Journal of financial economics, 53(3), 353-384. 
Hermalin, B. E., \& Weisbach, M. S. (1991). The Effects of Board Composition and Direct Incentives on Firm Performance. Financial Management, 20, pp. 101-112.

Hermalin, B. E., \& Weisbach, M. S. (1998). Endogenously Chosen Boards of Directors and Their Monitoring of the CEO. American Economic Review, 88, pp. 96-118.

Hodges, R., Wright, M., \& Keasey, K. (1996). Corporate governance in the public services: Concepts and issues. Public Money \& Management, 16(2), 7-13.

Hu, A., \& Kumar, P. (2004). Managerial entrenchment and payout policy. Journal of Financial Quantitative Analysis, 39, pp. 759-790

Krivogorsky, V. (2006). Ownership, board structure, and performance in continental Europe. The International Journal of Accounting, 41, pp. 176-197.

Kumar, P., \& Sivaramakrishnan, K. (2008). Who Monitors the Monitor? The Effect of Board Independence on Executive Compensation and Firm Value. Review of Financial Studies, 21(3), pp. 1371-1401.

La Porta, R., Lopez-de-Silanes, F., Shleifer, \& A., Vishny, R. (2000). Agency problems and dividend policies around the world. Journal of Finance, 55(1), pp.1-33.

Linck, J. S., Netter, J. M., \& Yang, T. (2008). The Determinants of Board Structure. Journal of Financial Economics, 87, pp. 308-387.

MacAvoy, P., \& Millstein, I. M. (1999). The Active Board of Directors and Its Effect on the Performance of the Large Publicly Traded Corporation". Journal of Applied Corporate Finance, 11(4), pp. 8-20.

Martinez, M., Jamison, M., \& Tillmar, M. (2013). Public utilities corporate governance. Journal of Management \& Governance, 17(4), 827-833.

Menozzi, A., Urtiaga, M., Vannoni, D. (2012). Board Composition, Political Connections and Performance in StateOwned Enterprises. Industrial and Corporate Changement, 21(3), pp. 671-698.

Monteduro, F. (2014). Public-private versus public ownership and economic performance: evidence from Italian local utilities. Journal of Management and Governance, 18, pp. 29-49.

Morck, R., Shleifer, A., \& Vishny, R. W. (1988). Management ownership and market valuation: An empirical analysis. Journal of financial economics, 20, 293-315.

Moursli, R. D. (2019). The effects of board independence on busy directors and firm value: Evidence from regulatory changes in Sweden. Corporate Governance: An International Review (forthcoming)

Osborne, S. P., Brown, K. (2005). Managing change and innovation in public service organizations. London: Routledge.

Palia, D. (2000). The impact of regulation on CEO labor markets. The RAND Journal of Economics, 165-179.

Palmberg, J. (2015). The performance effect of corporate board of directors. European Journal of Law and Economics, 40, pp.273-292.

Sharma, V. (2011). Independent directors and the propensity to pay dividends. Journal of Corporate Finance, 17(4), 1001-1015.

Shleifer, A., \& Vishny R. (1997). A Survey of Corporate Governance. Journal of Finance, 52(2), pp. 737-84.

Tillmar, M. (2009). No longer so strange? (Dis)trust in municipality: Small business relationships. Economic and Industrial Democracy, 30(3), 401-428.

Weisbach, M. (1988). Outside Directors and CEO Turnover. Journal of Financial Economics, 20, pp. 431-60.

Yermack, D. (1996). Higher Market Valuation of Companies with a Small Board of Directors. Journal of Financial Economics, 40(2), pp. 185-212.

Zahra, S.A., \& Pearce, J.A. (1989). Boards of directors and corporate financial performance: a review and integrative model. Journal of Management, 2, pp. 291-334. 